\title{
MEDIA FILM SEBAGAI SARANA PEMBELAJARAN LITERASI DI SMA WISUDA PONTIANAK
}

\author{
Mai Yuliastri Simarmata ${ }^{1}$, Dewi Leni Mastuti ${ }^{2}$ Muhammad \\ Thamimi $^{3}$, Melia ${ }^{4}$, Ramadhan Kusuma Yudha ${ }^{5}$, Aqis Yuliansyah ${ }^{6}$ \\ ${ }_{1,2,3,4,5,6}$ Program Studi Pendidikan Bahasa dan Sastra Indonesia Fakultas Bahasa dan Seni \\ IKIP PGRI Pontianak, Jalan Ampera No. 88 \\ 1e_mail maiyuliastrisimarmata85@gmail.com
}

\begin{abstract}
Abstrak
Kegiatan pengabdian berupa workshop dengan judul Media Film Sebagai Sarana Pembelajaran Literasi di SMA Wisuda Pontianak. Peserta dalam kegiatan Pegabdian berjumlah 20 Siswa. Tujuan dari dilaksanakan kegiatan pengabdian kepada masyarakat dalam bidang pendidikan adalah (1) Memberikan pemahaman dan kesadaran literasi bagi generasi muda(2) Media Film dapat meningkatkan minat baca siswa (3) Melatih keterampilan menulis berdasarkan apa yang lihat dengan bahasa dan kalimatnya sendiri. Kegiatan ini sangat produktif dalam mengembangkan keterampilan menulis yang dikhususkan pada menulis teks drama.
\end{abstract}

Kata Kunci: Literasi, media Film, keterampilan menulis, teks drama

\section{Abstract}

The service activity was in the form of a workshop with the title Film Media as a Literacy Learning Facility at Pontianak Graduation High School. The participants in Pegabdian activities were 20 students. The purpose of implementing community service activities in the field of education is (1) Providing literacy understanding and awareness for the younger generation (2) Film media can increase students reading interest (3) Practice writing skills based on what they see in their own language and sentence. This activity was very productive in developing writing skills specifically for writing drama texts.

Keywords: Literacy, film media, writing skills, drama texts

\section{PENDAHULUAN}

Pendidikan merupakan suatu hal yang penting bagi manusia, karena pendidikan bertujuan untuk mendidik dan membangun agar manusia dapat memiliki keterampilan dan kecerdasan.Pendidikan mendukung program pemerintah dalam mencerdaskan kehidupan bangsa.Pendidikan juga berperan dalam pembangunan bangsa.Generasi muda merupakan agent of change.Maka, generasi muda harus memiliki sikap peduli dan kritis terhadap kondisi yang ada.

Bahan bacaan seperti surat kabar, majalah, dan lain-lain. Bentuk publikasi massa yang biasa membentuk pendapat umum, siaran radio dan televisi serta film (audio visual media), lembaga atau asosiasi dalam masyarakat seperti masjid atau 
gereja tempat menyampaikan khotbah, dan juga lembaga pendidikan formal ataupun informal. Dalam perkembangan metode pembelajaran saat ini, metode belajar konvensional dan membaca buku dirasa kurang efektif, maka perlu ada inovasi dalam metode pembelajaran.Salah satunya melalui media audio visual atau film.

Film atau sering juga disebut movie merupakan salah satu jenis seni yang dapat digunakan untuk media pembelajaran. Pendidikan melalui media film ini dapat digunakan sebagai metode pembelajaran dalam pendidikan literasi. Apabila dilihat dari kemajuannya, teknologi dan industri perfilman sangat berhasil menarik minat generasi muda untuk menyaksikan film.Peluang tersebut dapat kita manfaatkan untuk hal yang bersifat positif, misalnya pendidikan.

Rendahnya minat literasi bagi orang Indonesia menjadi kabar duka bagi peradabanbangsa Indonesia.Akibatnya, masyarakat Indonesia mudah dipengaruhi olehkabarhoaxyangtidak jelas sumber datanya, disebabkan oleh lemah dalam berpikirkritis.Meningkatkanliterasibagi masyarakat Indonesia menjadisalah satu caramenumbuhkankemampuanberpikirkritisterhadap informasi apapun.

Hosnan (2014: 111) menyatakan bahwa media adalah segala sarana atau bentuk komunikasi nonpersonal yang dapat dijadikan sebagai wadah dari informasi pelajaran yang akan disampaikan kepada anak didik serta dapat menarik minat serta perhatian, sehingga tujuan dari pada belajar dapat tercapai dengan baik. Sementara Sadiman (2008: 7) menjelaskan media pembelajaran adalah segala sesuatu yang dapat digunakan untuk menyalurkan pesan dari pengirim ke penerima pesan. Dalam hal ini adalah proses merangsang pikiran, perasaan, perhatian, dan minat serta perhatian siswa sehingga proses belajar dapat terjalin. Selanjutnya, Kurniawan (2011: 135) menyatakan media adalah penyaluran pesanpesan pembelajaran sehingga pesan atau materi pembelajaran tersebut mampu merangsang pikiran, perhatian, perasaan, dan minat siswa sehingga terjadi proses belajar pada siswa secara efektif.

Secara konseptual, pengertian literasi yang diadopsi dan disosialisasikan Kemendikbud bukanlah sekadar kegiatan membaca dan menulis.Lebih dari itu, literasidipahami sebagai kemampuan mengakses, mencerna, dan memanfaatkan 
informasi. Melalui pra observasi budaya literasi dari salah satu SMA di Pontianak didapatkan bahwa mayoritas siswa belum menunjukkan minat pada literasi. Hal tersebut tercermin dari sudut perpustakaan yang sepi dari kunjungansiswapada jam-jam istirahat.Disamping itu, rendahnya budaya membacasiswadanlebihmengutamakan media gadget sebagai aktivitas keseharian.

Tamburaka ( 2013: 8) . Kemampuan literasi media tidak muncul secara instan, namun memerlukan suatu proses yang panjang. Kemampuan literasi media dapat dimulai dari lingkungan terkecil yaitu keluarga, baru kemudian dikembangkan ke lingkungan yang lebih luas seperti misalnya sekolah dan masyarakat. Ketika seseorang melek media, ia akan memiliki peta yang jelas untuk mengarahkan diri secara lebih baik di dunia media sehingga ia bisa memperoleh pengalaman dan informasi yag diingkikan tanpa teralihkan oleh pesan - pesan yang merusak dirinya (Potter, 2005: 14).

Berdasarkan catatan UNESCO (Organisasi Pendidikan, Ilmu Pengetahuan, danKebudayaan Perserikatan Bangsa-Bangsa). Indeks membaca bangsa Indonesia menurutUNESCO (2012) hanya 0,001. Artinya, di antara 1.000 orang, hanya satu orangyangmembaca secara serius. Demikian pula catatan survei MostLiteratedNationinTheWorld(2015) menempatkan Indonesia pada peringkat ke-60 dari 61 negara.

Tujuan diadakan pengabdian (1) Memberikan pemahaman dan kesadaran literasi bagi generasi muda (2) Media Film dapat meningkatkan minat baca siswa (3) Melatih keterampilanmenulis berdasarkan apa yang lihat dengan bahasa dan kalimatnya sendiri (4) Dapat membuat Naskah drama yang menarik

\section{A. Pengertian Media Film}

Media dan film sangat erat sekali hubungannya, film merupakan salah satu jenis media dan keberadaannya sangat digemari oleh masyarakat, karena merupakan media pandang dengar yang menyampaikan pesan dengan alur cerita yang bisa dibuat semenarik mungkin. Berdasarkan penjelasan mengenai media dan film yang telah dikemukakan di atas, maka dapat diambil kesimpulan bahwa media film adalah alat komunikasi visual yang digunakan sebagai perantara ataupenghubung antara dua pihak, yaitu antara sumber pesan dan penerima pesan 
atau informasi yang berupa gambar hidup disertai dengan suara yang digunakan untuk membantu seseorang dalam menceritakan informasi dan sejarah serta untuk mempelajari tentang ide baru.

\section{B. Manfaat Media Film}

Menurut Rusman (2013: 222) Penggunaan media film, siswa diharapkan dapat menerima materi pelajaran, memperoleh persepsi dan pemahaman yang sama benar. Sedangkan guru diharapkan mampu memotivasi peserta didik selama proses pembelajaran berlangsung dan membantunya mengingat kembali dengan mudah berbagai macam pengetahuan dan keterampilan yang telah dipelajari. Media jenis ini dapat digunakan untuk menyajikan bagian-bagian dari suatu proses dan prosedur secara utuh sehingga memudahkan siswa dalam mengamati dan menirukan langkah-langkah suatu prosedur yang harus dipelajari.

\section{Karakteristik Media Film Sebagai Media Pembelajaran}

Media merupakan sarana komunikasi yang digunakan untuk menyampaikan dan menyebarluaskan pesan-pesanMedia yang memilikijangkauansangatluas. Media interaktifyang dapatmenggabungkanseluruhmedia informasi, meliputi: audio visual, animasi, image danteks.

Secara singkat apa yang dapat dilihat pada sebuah film hendaknya dapat memberikan hasil yang nyata bagi audien. Dalam menilai baik tidaknya sebuah film.Hamalik (2010) mengemukakan bahwa film yang baik memiliki karakteristik atau ciri-ciri sebagai berikut:

1. Dapat menarik minat siswa/ anak.

2. Benar dan autentik.

3. Up to datedalam setting, pakaian, dan lingkungan.

4. Sesuai dengan kematangan audien.

5. Perbendaharaan bahasa yang dipergunakan secara benar.

6. Kesatuan dan squence-nya cukup teratur.

7. Teknis yang dipergunakan cukup memenuhi persyaratan dan cukup memuaskan.

Secara ringkasnya dapat dikatakan bahwa suatu film dikatakan baik bila memenuhi beberapa syarat, diantaranya adalah sangat menarik minat siswa dan 
autentik, up to date, sesuai dengan tingkat kematangan anak, bahasanya baik dan tepat, mendorong keaktifan siswa sejalan dengan isi pelajaran dan memuaskan dari segi teknik.

\section{Keunggulan dan Kelemahan Media Film}

Film kurang efektif jika diberikan tersendiri,karena itu harus digunakan dengan metode lain setelah penayangan film selesai. Film berperan sebagai penarik perhatian yang bersifat menghibur.Berikut beberapa keunggulan dan kelemahan media film.

\section{Keunggulan Film}

a. Menarik perhatian.

b. Dapat menunjukkan langkah atau tahapan yang diperlukan untuk melakukan tugas tertentu.

c. Dapat menayangkan peristiwa atau acara yang telah terjadi.

d. Dapat dipercepat dan diperlambat untuk menganalisis tindakan atau pertumbuhan tertentu.

e. Dapat diperbesar agar dapat dilihat dengan mudah.

f. Dapat diperpendek dan diperpanjang waktunya.

g. Dapat memotret kenyataan.

h. Dapat menimbulkan emosi.

i. Dapat digunakan untuk menggambarkan tindakan secara jelas dan cermat.

\section{Kelemahan Film}

a. Mahal.

b. Jika digunakan kurang tepat akan berdampak kurang baik.

c. Kurang efektif untuk memberikan pengajaran yang sesungguhnya.

d. Baru bermanfaat jika digunakan sebagai pelengkap dari metode pengajaran yanglain.

\section{E. Pengertian Literasi Media}

Iriantara (2006:79 ) mendefinisikan literasi adalah kemampuan seorang individu untuk membaca dan menulis dengan memahami pernyataan singkat yang 
terkait dengan kehidupannya. literasi tidak hanya didefiniskan sebagai kemampuan membaca dan menulis, melainkan juga "kemampuan menempatkan,mengevaluasi,menggunakan dan mengkomunikasikan melalui berbagai sumberdaya termasuk sumber daya teks, visual, suara, dan video. Selanjutnya, Tamburaka 2013: 8. Kemampuan literasi media tidak muncul secara instan, namun memerlukan suatu proses yang panjang. Kemampuan literasi media dapat dimulai dari lingkungan terkecil yaitu keluarga, baru kemudian dikembangkan ke lingkungan yang lebih luas seperti misalnya sekolah dan masyarakat. Ketika seseorang melek media, ia akan memiliki peta yang jelas untuk mengarahkan diri secara lebih baik di dunia media sehingga ia bisa memperoleh pengalaman dan informasi yag diingkikan tanpa teralihkan oleh pesan - pesan yang merusak dirinya (Potter, 2005: 14).

Tujuan literasi media atau melek media adalah memberikan kontrol terhadap penafsiran peran media.Pesan yang disampaikan oleh media kebanyakan bersifat bias, sehingg memerlukan filter untuk mencegahkesalahan dalam penafsiran.Sebagai suatu kemampuan, literasi media atau melek media dapat dimiliki oleh semua orang dan dapat dikembangkan.Namun untuk mampu mencapai analisis pesan, dibutuhkan tingkat kematangan emosional dan intelektual.

Baran (2002: 50 - 53) mengidentifikasikan bahwa ada lima unsur mendasar kara-kteristik literasi media atau melek media yaitu; a. Adanya kesadaran akan dampak media. Media dapat merubah dunia dengan dampak dari konten yag diberikan kepada khalayak. Jika kita mengabaikan dam-pak media, kita akan terbawa ke arah perubahan yang dikonstruksi oleh media; b. Adanya pemahaman tentang proses komunikasi massa. Jika kita mengetahui komponen - komponen dari proses komunikasi massa dan bagaimana mereka berhubungan satu sama lain kita dapoat membentuk ekspektasi tetang bagaimana mereka bisa melayani kita; c. Adanya strategi menganalisis dan mendiskusikan pesan media. Untuk mengkonsumsi pesan media dibutuhkan landasan yang menjadi dasar pemikiran dan refleksi; d. Pemahaman tentang konten media sebagai teks yang memberikan wawasan tentang budaya dan kehidu-pan kita. Berkaitan dengan bagaimana kita 
mengetahui tentang orang, sikap, tata nilai diperoleh melalui komunikasi. Untuk budaya modern pesan media semakin mendomiasi komunikasi, membentuk pemaha-man dan wawasan budaya; e. Kemampuan untuk menikmati, memahami dan menghargai isi media.Dampak dari adanya literasi media ada tiga, yaitu: pertama, seseorang menjadi memiliki sikap preventif terhadap terpaan media, bukan resisten. Kedua, biasanya jika seseorang yang sudah media literate,tidak cukup hanya dengan menonton televisi saja, tetapi juga membuka twitter, mendengarkan radio, membaca koran atau membaca buku, mempunyai tanggung jawab sosial, setidaknya pada keluarga dan lingkungannya dan yang ketiga seseorang mampu untuk mengadvokasi terpaan media.

\section{F. Konsep Literasi Media}

Literasi media menurutTamburaka(2013), merupakan suatu rangkaiangerakan melek media, yaitu: gerakanmelek media dirancang untukmeningkatkan kontrol individuterhadap media yang merekagunakan untuk mengirim danmenerima pesan. Hal yang senada juga disampaikan oleh Baran (2010) mengatakan bahwa literasi media sebagai suatu rangkaian kegiatan melek media yaitu gerakan melek media dirancang untuk meningkatkan kontrol individu terhadap media yang mereka gunakan untuk mengirim dan menerima pesan.Kemudian, dalam hal ini melek media di pandang sebagai sebuah keterampilan yang bisa berkembang di dalam sebuah rangkaian di mana kita tidak selalu melek terhadap media dalam semua situasi, setiap waktu terhadap semua media. Sementara Potter (2005) mendefinisikan literasi media sebagai satu perangkat perspektif di mana kita secara aktif memberdayakan diri kita sendiri dalam menafsirkan pesan-pesan yang kita terima dan bagaimana cara mengantisipasinya.

Dari pemaparan media literasi di atas dapat disintesiskan bahwa aktivitas yang menekankan aspek edukasi di kalangan masyarakat agar mereka tahu bagaimana mengakses, memilih program yang bermanfaat dan sesuai kebutuhan yang ada. Permasalahan yang ada seiring dengan derasnya arus informasi media, masyarakat pun dibuat kebingungan dan tidak mampu memilah, menyeleksi, serta memanfaatkan informasi yang sudah mereka peroleh. 


\section{G. Cakupan Literasi Media}

Literasi media adalah kemampuan untuk memahami, menganalisis, dan mendekonstruksi pencitraan media. Kemampuan untuk melakukan hal ini ditujukan agar pemirsa sebagai konsumen media (termasuk anak-anak) menjadi sadar (melek) tentang cara media dikonstruksi (dibuat) dan diakses.Menurut Tamburaka (2013) literasi media berasal dari bahasa Inggris yaitu Media Literacy terdiri dari kata yakni media adalah tempat pertukaran pesan dan literacy berarti melek, kemudian dikenal dalam istilah Literasi Media yang mana melek dapat diartikan pada kemampuan khalayak terhadap media dan pesan media massa dalam kontek komunikasi massa.

Literasi media muncul dan mulai sering dibicarakan karena media seringkali dianggap sumber kebenaran, dan pada sisi lain, tidak banyak yang tahu bahwa media memiliki kekuasaan secara intelektual di tengah publik dan menjadi medium untuk pihak yang berkepentingan untuk memonopoli makna yang akan dilempar ke publik. Karena pekerja media bebas untuk merekonstruksikan fakta keras dalam konteks untuk kepentingan publik dan merupakan bagian dalam kebebasan pers. Tanggung jawab atas suatu hasil rekonstruksi fakta adalah berada pada tangan jurnalis, yang seharusnya netral dan tidak dipengaruhi oleh emosi dan pendapatnya akan narasumber, dan bukan pada narasumber.

\section{H. Komponen Literasi Media}

Literasi media merupakan kemampuan seseorang untuk menggunakan berbagai media guna mengakses, analisis serta menghasilkan informasi untuk berbagai keperluan. Dalam kehidupan sehari-hari seseorang akan dipengaruhi oleh media yang ada di sekitar kita berupa televisi, film, radio, musik terekam, surat kabar dan majalah. Dari media itu masih ditambah dengan internet bahkan kini pun melalui telepon seluler dapat diakses.

Literasi media dapat didefinisikan menggunakan pendekatan trikotomi yang mencakup 3 bidang yaitu :

a. Literasi media bermakna memiliki akses ke media, memahami media dan menciptakan/mengekspresikan diri sendiri dengan menggunakan media 
(Livingstone 2005). Akses media yaitu kemampuan menggunakan fungsi dan kompetensi navigasi (mengubah saluran televisi, menggunakan sambungan Internet): kompetensi mengendalikan media (misalnya menggunakan sistem terpasang interaktif, melakukan transaksi melalui Internet); pengetahuan tentang legislasi dan peraturan lain dalam bidang tersebut (misalnya kebebasan berbicara, mengungkapkan pendapat, perlindungan privasi).

b. Pemahaman artinya memiliki kemapuan untuk memahami/menafsirkan serta memperoleh sudut pandang terhadap isi media dan kritis.

c. Menciptakan, mencakup kegiatan interaksi dengan media (misalnya berbicara di radio, ikut serta dalam diskusi di internet) juga menghasilkan isi media.

Jadi literasi media adalah masalah ketrampilan, pengetahuan dan kompetensi, juga tergantung pada institusi, lembaga dan teknik untuk mediasi informasi dan komunikasi. Secara analitis, konsep literasi media digunakan pada aras perorangan dan masyarakat.

Istilah media mencakup semua media komunikasi, kadang-kadang digunakan istilah media massa merujuk ke semua media yang dimaksudkan untuk mencapai audisi sangat besar seperti televisi siaran dan bayar, radio, film, surat kabar dan majalah. Sering pula istilah "dalam semua media dan format" mengacu pada komunikasi dan diseminasi informasi dalam berbagai media berlainan serta berbagai format (teks, grafik, foto, tabel statistik dll).

Untuk memahami definisi literasi media yang telah diuraikan diatas, maka perlu diketahui tujuh elemen utama dalam literasi media yaitu:

1. Sebuah kesadaran akan dampak media terhadap individu dan masyarakat

2. Sebuah pemahaman tentang komunikasi massa

3. Pengembangan strategi - strategi yang digunakan untuk menganalisis dan membahas pesan - pesan media

4. Sebuah kesadaran akan isi media sebagai "teks" yang memberikan wawasan ddan pengetahuan ke dalam budaya kontemporer manusia dan diri manusia sendiri 
5. Peningkatan kesenangan, pemahaman, dan apresiasi terhadap isi media (Silverblatt, 2012:12)

Berdasarakan definisi dan elemen - elemen tersebut literasi media dapat diklasifikasi ke dalam beragam tipe seperti :

1. Berdasarkan media yang dituju; terdiri dari literasi, literasi media (dalam arti sempit), dan literasi media baru;

2. Berdasarkan tingkat kecakapan; terdiri dari tingkat awal, tingkat menengah, dan tingkat lanjut. Tingkat awal biasanya berupa pengenalan media, terutama mengenai efek positif dan negatif yang potensial diberikan oleh media.

Literasi media tingkt menengah bertujuan menumbuhkan keahlian memahami/menafsirkan pesan. Sedangkan pada tingkat lanjut akan menghasilkan output kemampuan memahami pesan secara lengkap hingga pada produksi pesan, struktur pengetahuan terhadap media yang relatif lengkap serta pemahaman kritis pada level aksi misalnya memberi masukan dan kritik pada organisasi dan menggalang aksi untuk mengritik media.

Proses di dalam aktivitas penguatan literasi media sangat dipengaruhi oleh tujuan kegiatan tersebut. Bila tujuan dari kegiatan literasi media adalah mengenalkan efek media, prosesnya tentu saja mendahulukan mengakses isi pesan yang diasumsikan berefek tak baik. Sementara itu, bila tujuan untuk mengenalkan aspek produksi, tentu saja prosesnya melibatkan produksi dan semua aspeknya. Konteks juga sangat berpengaruh pada kegiatan literasi media. Maraknya pembicaraan tentang pornografi membuat kegiatan literasi media sebaiknya juga merujuk pada kasus-kasus pornografi di media. Aspek framework terutama berkaitan dengan aspek produksi. Kerangka pandang konten media mempengaruhi kegiatan literasi media, terutama yang berkaitan dengan motif komersial. Terakhir, kegiatan literasi media seharusnya menjadikan individu khalayak media memiliki nilai tersendiri, yang mana konten media yang dipandang baik dan dipandang buruk.

Berdasarkan uraian di atas maka kegiatan pengabdian kepada masyarakat perlu dilaksanakan dalam bentuk workshop di SMA Wisuda Pontianak. 


\section{METODE}

Kegiatan pengabdian kepada masyarakat dilaksanakan di SMA Wisuda Kota Pontianak. Peserta dalam kegaitan pengabdian berjumlah 22 siswa. Metode yang digunakan dalam kegiatan pengabdian kepada masyarakat adalah tanya jawab, demontrasi, diskusi, dan ceramah, serta menghasilkan produk berupa naskah drama yang berkaitan dengan pendidikan karakter. Untuk melatih kemampuan literasi siswa supaya lebih bergairah dengan menggunakan media film dengan tema pendidikan karakter. Berdasarkan hasil kegaitan pengabdian yang dilaksanakan siswa sangat tertarik dan semangat dalam merespon media yang telah disediakan serta dapat menulis naskah drama yang menarik sesuai dengan tema yang telah ditentukan. Kegaitan pengadian disambut baik oleh pihak sekolah.

\section{HASIL DAN PEMBAHASAN}

Berdasarkan pengamatan selama kegiatan berlangsung. Respon siswa sangat positif. Ketika pemateri menyampaikan materi serta memutarkan video yang berkaitan dengan pendidikan karakter. Banyak ssiwa yang bertanya. Serta memberikan contoh-contoh pendidikan karakter yang semakin hari etika dan sopan santun siswa terkait tuturan sudah mulai tidak sesuai dengan konteks. Oleh karena itu, diakhir kegaitan pemateri membagikan siswa dalam bentuk kelompok untuk membuat naskah drama. Hal ini dilakukan untuk mengukur kemampuan literasi siswa melalui media film. 


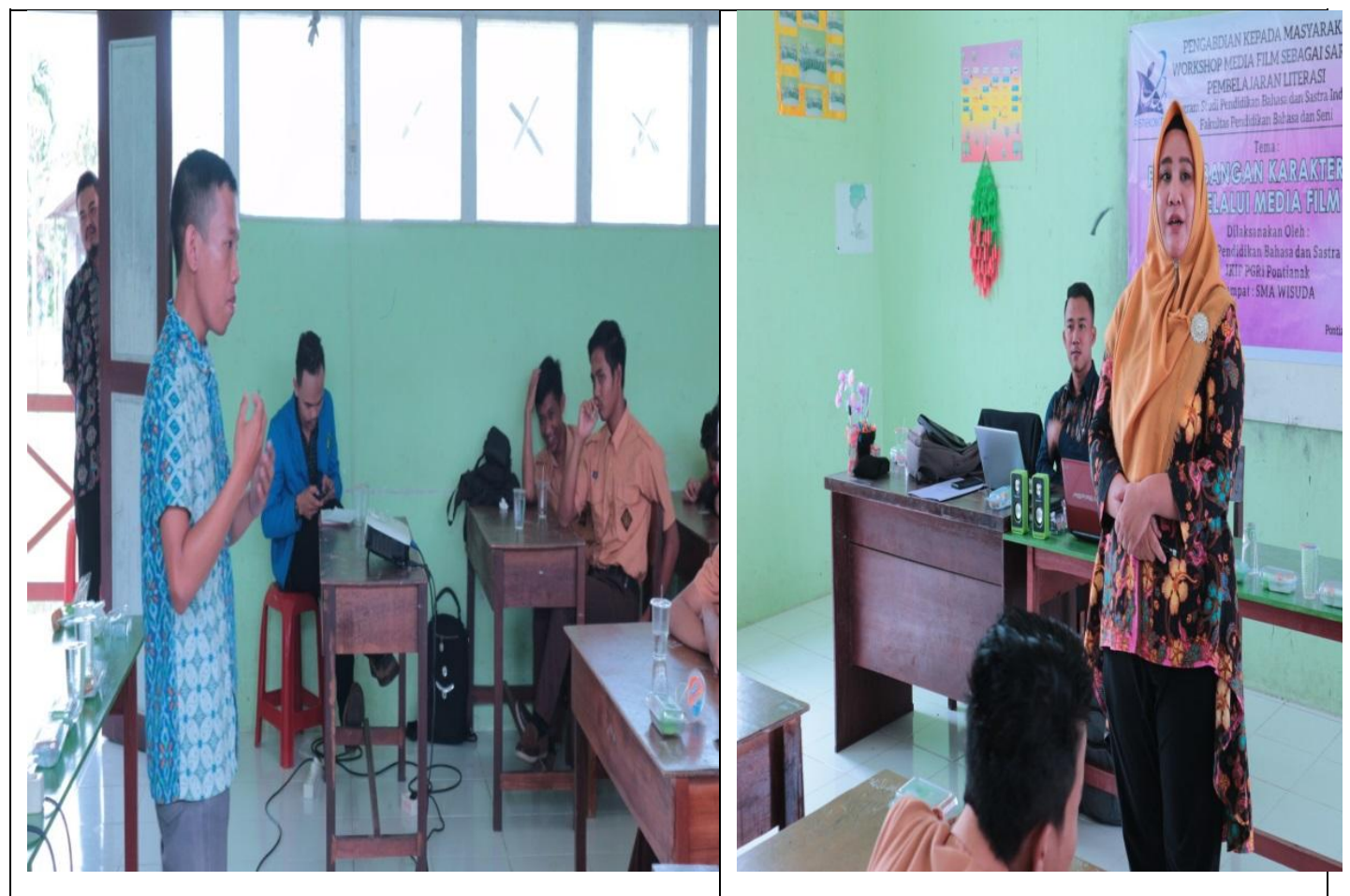

Gambar 1. Pemateri menjelaskan terkait Media Film sebagai sarana literasi
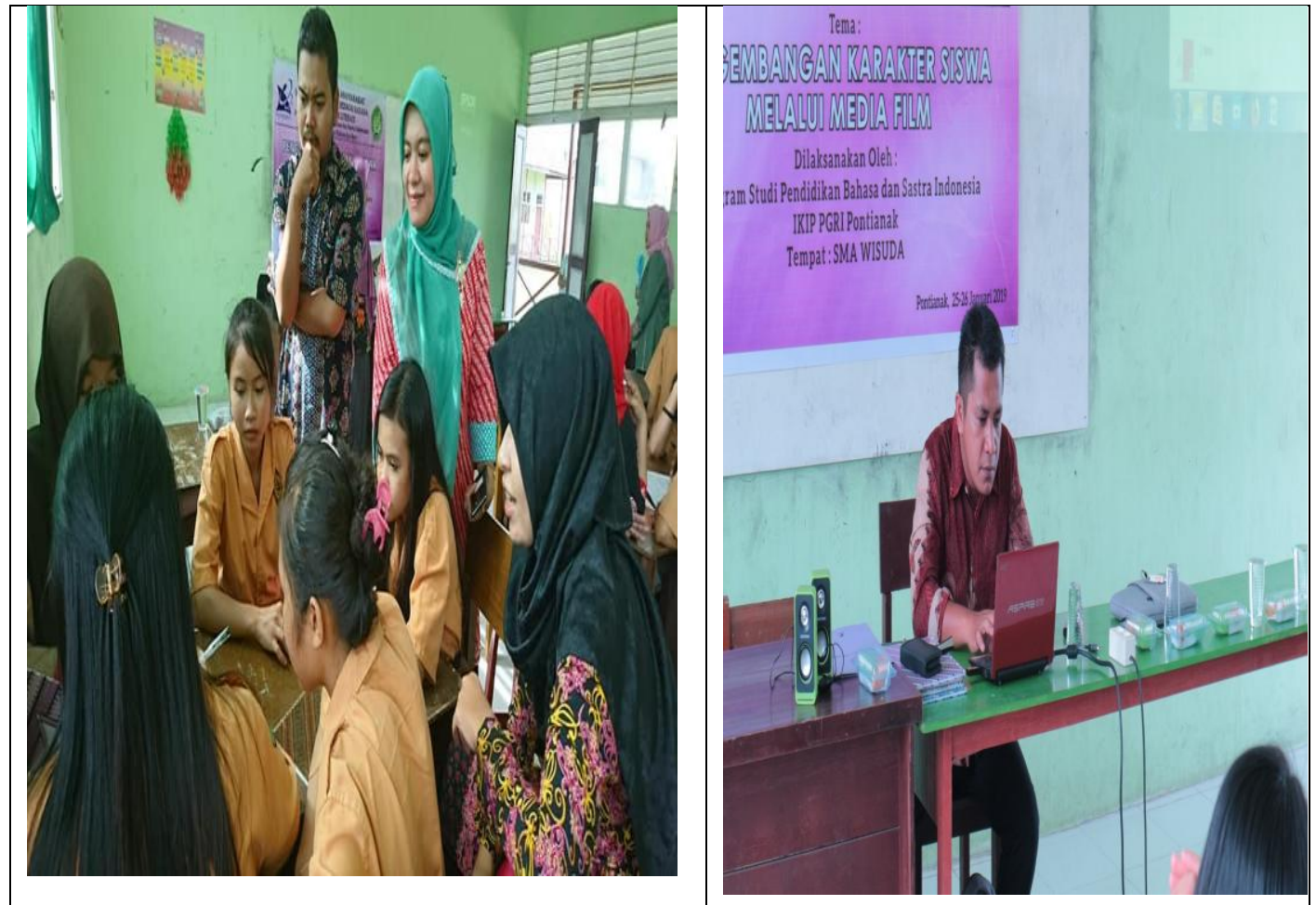

Gambar 2. Pemateri mengamati siswa berdiskusi dalam pembuatan Naskah drama 


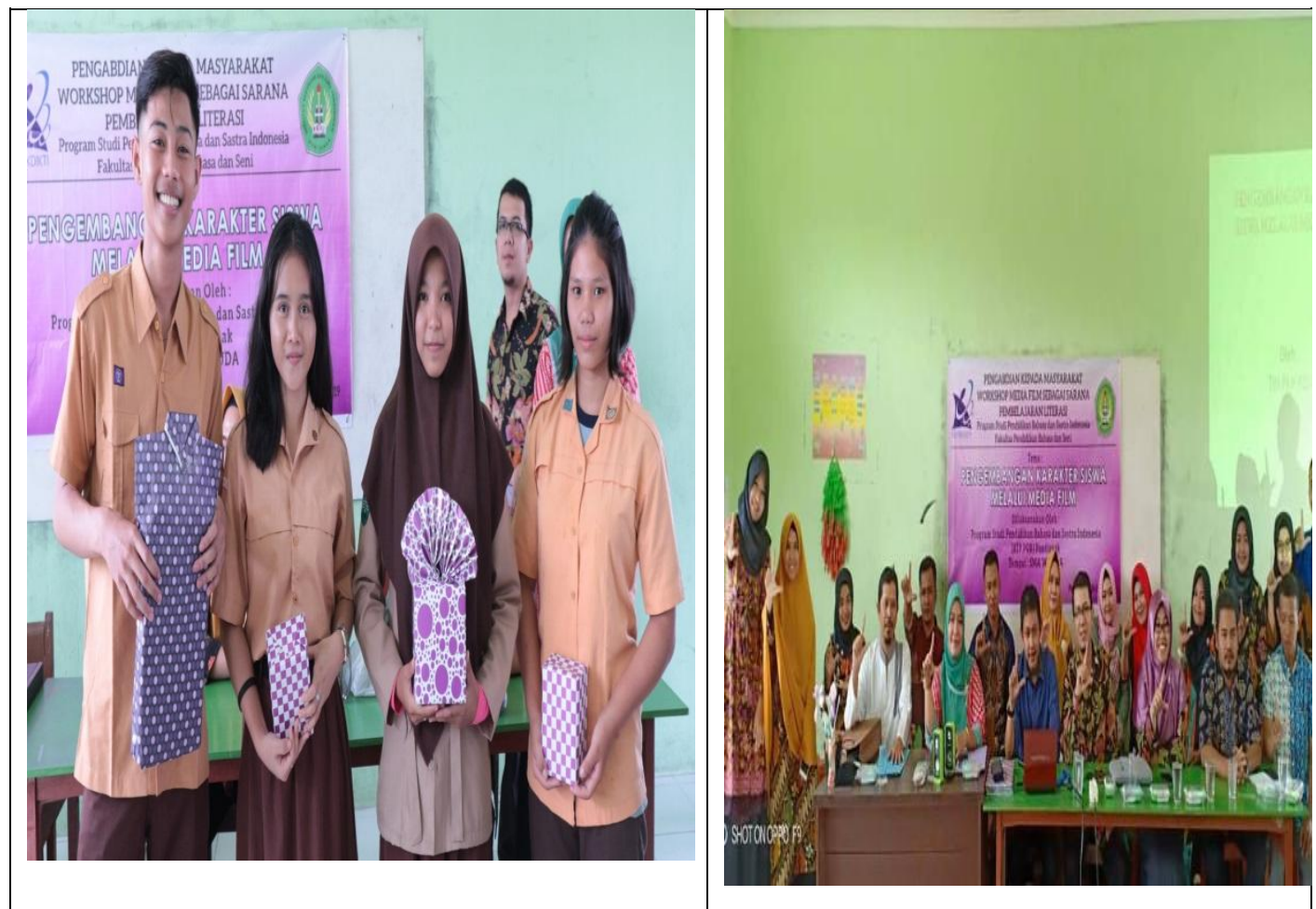

Gambar 3. Pemberian Reword bagi kelompok yang berprestasi dan tim pelaksana pengabdian

Berdasarkan hasil pengabdian kepada masyarakat diperoleh peningkatan hasil literasi siswa. Dengan media flim yang ditanyangkan dan penyampaian materi yang jelas. Siswa sangat respon bahkan semangat dalam mengerjakan produk berupa naskah drama yang berkaitan dengan pendidikan karakter. Diakhir kegiatan kelompok yang menghasilkan naskah drama yang bagus maka pemateri memberikan reword. Hal ini menjadi penyemangat bagi siswa.

\section{SIMPULAN}

Kegiatan pengabdian dilaksanakan selama 2 hari atau disetarakan 15 jam pertemuan yakni pada 26-27 Januari 2018 di SMA Wisuda Pontianak. Kegiatan yang dilaksanakan berupa workshop pembelajaran media film sebagai sarana literasi terlaksana dengan baik. Hal tersebut ditandai dengan hadirnya semua siswa untuk mengikuti kegiatan workshop dan siswa sangat antutias dalam membuat produk berupa teks drama. Saran yang dapat diberikan adalah khalayak sasaran perlu dijangkau semua, sehingga tidak hanya di SMA Wisuda saja, melainkan semua siswa di Kota Pontianak diikutsertakan. 


\section{DAFTAR PUSTAKA}

Hosnan.2014.Pendekatan Saintifik dan Konstektual dalam Pembelajaran Abad 21. Kunci Sukses Implementasi Kurikulum 2013: Bogor. Ghalia Indonesia.

Kurniawan, Deni. 2011. Pembelajaran Terpadu: Bandung. Pustaka Cendekia Utama.

Sardiman. 2007. Interaksidan Motivasi Belajar Mengajar: Jakarta. Raja Grafindo Persada.

Tambaruka, Apriadi. 2013. Literasi Media: Cerdas Bermedia Khalayak Media Massa: Jakarta: Rajawali Press.

Potter, W, James. 2005. Media Literacy: A Cognitive Aprroach.America: Sage Publication. 